\title{
O teatro simbolista de Antônio Patrício: um
}

\section{teatro do verbo}

Simone NACAGUMA ${ }^{1}$

Universidade Estadual Paulista - UNESP

Embora a maioria das obras críticas sobre o teatro português traga, logo de início, aquela velha questão acerca da existência ou não de um "teatro português poeticamente autônomo" (PICCHIO, 1969, p. 19), tal questionamento não se faz tão pertinente neste trabalho, visto que essa questão já foi exaustivamente fundamentada através da importância históricoliterária de poetas que, dando vazão ao seu gênio dramático, produziram também as mais importantes obras dramáticas: Gil Vicente, António Ferreira, Garret e Fernando Pessoa.

Desse modo, apesar da produção teatral portuguesa não acompanhar os números de sua produção poética e de narrativa de ficção, não se pode desconsiderar a importância e a qualidade de sua literatura dramática que veio veementemente contribuindo de forma positiva em quase todos os movimentos estéticoliterários em Portugal. Portanto, embora em escala reduzida, verificamos a existência de uma produção dramática simbolista em Portugal que, agora não menos que na poesia, também faz por merecer alguma notoriedade, em razão do desafio a que alguns autores se colocaram ao tentar transpor os ideais simbolistas para o gênero em questão, o que, é forçoso admitir, não é tarefa das mais simples.

A violenta reação contra o positivismo que caracterizou toda a Europa nos fins do século XIX, afirmando novos movimentos estéticos e concepções espiritualistas, “só após 1890

\footnotetext{
${ }^{1}$ Possui mestrado em Letras (Letras Clássicas), área de concentração Literatura Portuguesa, pela Universidade de São Paulo (2002) e doutorado em Teoria e História Literária, área de concentração Literatura Portuguesa, pela Universidade Estadual de Campinas (2010). Possui experiência como professora de Literatura Brasileira e Portuguesa e Língua Portuguesa em ensino superior e em cursos de pós-graduação latu sensu. Desenvolve, atualmente, pesquisa de pós-doutoramento em Literatura Comparada, atuando nos seguintes temas: ficção contemporânea portuguesa e moçambicana, póscolonialismo, identidade. E-mail: snacaguma@terra.com.br.
} 
começa a fazer-se sentir no teatro português" (Ibid., p. 119). No entanto, nem sempre é possível determinar com precisão suas influências, visto que, além das novidades culturais chegarem a Portugal com uns bons anos de atraso, quando aportam, misturam-se a elementos de vagas anteriores, de modo que se torna complexa uma classificação da produção literária portuguesa sob critérios europeus.

Assim sendo, apesar do célebre manifesto "Le Symbolisme”, de Jean Moréas, datar de 1886, no que concerne ao teatro português do final do século XIX, o Simbolismo não despertou grande interesse, seja na produção de textos dramáticos, seja no público. Isto se deveu, em parte, ao contínuo sucesso em Portugal dos "dramas de assunto histórico e das peças de tendência naturalista" (REBELLO, 1968, p. 87) que, consequentemente, reprimiram qualquer desdobramento maior do Simbolismo no teatro, muito diferente do que ocorrera com a poesia. Daí, a constatação de um Simbolismo tardio no gênero dramático e uma produção esporádica de obras, as quais ainda guardavam, muitas vezes, características herdadas do teatro naturalista e dos dramas históricos.

Desse modo, enquanto, na França, Jean Moréas lança o seu manifesto simbolista, em Portugal, nesse mesmo ano, sobe ao palco do Teatro Nacional O Duque de Viseu, de H. Lopes de Mendonça que, "coincidindo com o apogeu da exploração e ocupação militar ultramarinas", representa uma das várias peças de tema histórico que se multiplicavam pelos palcos portugueses. E esse mesmo quadro permanece ainda em 1890, pois se, por um lado, há a introdução oficial do Simbolismo em Portugal com a publicação de Oaristos, de Eugênio de Castro; por outro lado, persiste o sucesso dos dramas históricos nos palcos portugueses, lembrando que justamente no ano de 1890 e, depois, em 1891, estreiam no Teatro Nacional, respectivamente, os dramas históricos de João da Câmara intitulados Afonso IV e Alcácer Quibir. Isso justificaria, também, o possível desinteresse dos 
dramaturgos por uma nova estética, tendo em vista um iminente fracasso diante do público ao apresentar-lhe "novas propostas", o que o comprova a experiência de João da Câmara com a peça $O s$ velhos que, estreando em 1893, "perante o desinteresse de uma platéia habituada às estridências do teatro ultra e neo-romântico", revelou-se uma tentativa frustrada de "implantação do realismo nos palcos portugueses" (Ibid., pp. 88-9).

Posto isso, não é difícil imaginar o insucesso nos palcos que também sofreria, no ano seguinte, a próxima peça de João da Câmara, O pântano, "obra largamente tributária da estética simbolista e, em especial, da dramaturgia de Maeterlinck, cuja Princesa Maleine irresistivelmente evocava". Entretanto, apesar do "diálogo balbuciante, pontuado de repetições e silêncios", que apontava para uma tentativa simbolista de João da Câmara, verifica-se ainda demasiada reminiscência "da herança melodramática do ultra-romantismo, o que diminuiu consideravelmente a eficácia desta tentativa renovadora" (Ibid., p. 94). Contudo, o dramaturgo consegue um notável equilíbrio no seu próximo trabalho, um drama simbolista intitulado Meia-noite (1900), no qual "funde o puro simbolismo de proveniência maeterlinckiana com um realismo poético já esboçado pelo autor em $A$ triste viuvinha (...)" (Ibid., pp. 94-5).

Vale ressaltar, ainda, que no teatro simbolista "o nome venerado pelos simbolistas portugueses será Maeterlinck" (PICCHIO, 1969, p. 291) cuja influência, embora já fosse notada em João da Câmara através da complicada ação de Meia-noite ou das "tenebrosas alucinações d' $O$ pântano", "os grandes representantes do primeiro teatro simbolista português serão Eugênio de Castro, Fernando Pessoa, Antônio Patrício e Raul Brandão".

Apesar das tentativas inovadoras dos "poemas em forma dramática" de E. de Castro, do "drama estático" de Pessoa e do "drama sintético" de Brandão, é no drama lírico de Antônio Patrício que encontramos uma interpenetração tão funda dos 
gêneros que praticamente "verso e prosa se indistinguem" (REBELLO, Op. cit., p. 96) na obsessiva tematização do amor e morte. É, pois, sob essa temática maior que se encontram três das suas quatro peças de tendência simbolista: Pedro, o cru (1918) - “a tragédia da saudade", poema dramático sobre o velho tema nacional acerca da morte de Inês de Castro, mas centrado na personagem do rei -; Dinis e Isabel (1919) - "o conto de primavera”, propõe dialeticamente a oposição entre espírito e carne; D. João e a máscara (1924) - "uma fábula trágica” que, segundo Urbano Tavares Rodrigues, deve ser considerada "a obra que melhor permite avaliar a apetência lusitana para o tema de D. Juan" (RODRIGUES apud Ibid., p. 96). Faltando mencionar O fim (1909), justamente a peça de estreia de Patrício, que consiste numa antevisão da queda iminente da monarquia portuguesa.

O teatro de Patrício, seja quanto à sua forma, seja quanto à sua temática, apresenta profunda complexidade, não sendo possível submetê-lo a uma única influência, o que se confirma através de suas próprias palavras: "as escolas literárias são verdadeiras cooperativas de consumo. É só matricular-se... e cozinhar" (PATRÍCIO apud CORREIA, 1959/1960).

A singularidade de seus dramas, entretanto, não o levou ao reconhecimento de seu valor, fosse pela crítica, fosse pelo público, pois "muitos falam do teatro português sem ao menos se lembrarem que elas existem" (RÉGIO apud CAMELO; PECANTE, 1992, p. 119), o que, provavelmente, deveu-se, em grande parte, a sua tendência simbolista. Isso porque é recorrente, em quase toda a crítica teatral, que uma peça de teatro simbolista não constituiria uma peça por excelência, dado os propósitos do vago, do sublime, do sinestésico, do sugestivo e do imaterial que a norteiam. Agravo ainda exercido pela forma singular com que a ação é concebida na peça simbolista que, em tese, propõe a sua anulação, tal como se verifica, por exemplo, no 'drama estático', O marinheiro, de Fernando Pessoa. 
Em relação ao problema de recepção dos dramas de Patrício, outro fator complicador foi a sua expressão bíbrida, em que os seus diálogos são constituídos por versos que, por sua vez, seguem os anseios da estética simbolista. Mesmo nas peças Pedro, o cru e Dinis e Isabel, nas quais o verso nem sempre predomina, indubitavelmente expressam poesia.

A exemplo da complexidade resultante dessa dicotomia prosa/poesia expressa na linguagem da peça D. João e a máscara, verifica-se que, enquanto todo o diálogo entre as personagens se apresenta em prosa, quando D. João e a Morte dialogam, as suas falas se traduzem, inicialmente, em versos de rimas alternadas e, depois, em versos de rimas paralelas, persistindo desta forma até o final:

\section{A MORTE}

Era eu que o teu tédio e a tua alma queria?...

\section{JOÃO}

Falena da manhã: eras Tu... Eu sabia...

Tinhas de vir assim, mantilha de manola, Uma manhã de Outono, em máscara sombria, Para eu te beijar, tens de ser espanhola!

A MORTE

Há um instante só que tu esqueces:

Primeiro beijo eu, e a seguir arrefeces...

D. JOÃO

É certo... a conquista sou eu.

A Morte é D. João se D. João morreu.

\section{A MORTE}

Tens frio?

D. JOÃO

Quero ri... quero rir... quero rir... e não rio.

Não penses um instante, oh! Não, que tenho frio: Estou a arder, estou a arder, e estou a arder por Ti:

Ó Máscara de Outono, ó meu amor, sorri... (Ibid., pp. 323-4)

Vale notar, ainda, que persiste nesta peça a preocupação com a sonoridade como em $O$ fim. Encontramos, por exemplo, a assonância do "i" (todos tônicos) marcando, além da rima, a cadência e o ritmo nestes versos: 
(...) Eu sabia...

Tinhas de vir assim, mantilha de manola,

Uma manhã de Outono, em máscara sombria.

E, juntamente com a assonância do “i", verifica-se a aliteração do "m" e a assonância do "a":

(...)Eu sabia...

Tinhas de vir assim, mantilha de manola,

Uma manhã de Outono, em máscara sombria, (...) (Ibid., p. 323-4)

Verifica-se, portanto, que o uso de figuras de efeitos sonoros, como a aliteração e assonância, é marcante em todas as falas em versos. Entretanto, no último quadro do quarto ato, no qual D. João, quase redimido, torna-se apenas João e a Morte, Sóror Morte, identificamos uma mudança na exploração desses recursos sonoros. A fala de D. João se torna mais branda resignada - e isto se expressa sonoramente através do predomínio de vogais semi-fechadas e fechadas em oposição a uma redução na frequência de palavras cuja tonicidade recaia justamente nas vogais abertas, o que, conjugada ao ritmo decorrente do conjunto de tônicas dos versos e ao enjambement, resulta num aceleramento do ritmo e da cadência e, portanto, num tom mais desesperado e clamoroso, tal como ilustra o trecho abaixo:

“D. JOÃO (falando à Morte)

A tua voz, que tem? ... Parece que desperta uma alameda de visões, entreaberta...

E depois, ao calar-se, é a quintessência, a causa - como entre acordes de órgão, numa pausa de tudo o que na vida, e sem saber, procuro, e vai enfim abrir como uma flor no escuro. Ó Máscara sem sono, se tu vens, se tu vens nesta manhã de Outono, p'ra me dizer enfim o sentido da vida, numa casa sem luz, há a Manhã escondida, Doces, doces as mãos, - como de folhas mortas, Acordando a matilha e descerrando as portas..." (Ibid., p. 326) 
Encontramos, desse modo, além da presença de rimas paralelas, proporcionando maior aproximação rítmica entre os versos, as rimas internas entre versos contribuindo, também, para este propósito. Por exemplo, entre o primeiro e o segundo verso existe a aliteração do "v" (voz/visões), a assonância do “ ẽ " (tem/entreaberta), a assonância do "e" ao longo dos dois versos (que/ parece/ desperta/ alameda/ de/ visões/ entreaberta) e o enjambement ("Parece que desperta / uma alameda de visões, entreaberta"). Desse conjunto de elementos presentes na elaboração formal emergem, portanto, a sensação de aceleração do ritmo dos versos e o tom de desespero que, por sua vez, completa e reforça o conteúdo expresso.

A mudança de tom e de ritmo a que nos referimos anteriormente pode, então, ser comprovada através da comparação do trecho anterior com o que segue abaixo. Ou seja, através da fala de D. João que, buscando a remissão de seus erros, torna-se apenas João:

JOÃO (falando à Soror Morte)

Tu que tantos difamam, e poucos, como eu, ajoelhados amam. Irmã!... Deixa chamar-te. Imortal Bem Amada. Amendoeira de luz no caminho do Nada.

Ó Soror... Por piedade. A noite vem já perto.

Nem um botão de mirra em todo o meu deserto. A noite, a noite vem: é feita de basalto, e já não ergo as mãos, não posso, para o alto. (Ibid., p. 420)

Observa-se, assim, que, embora as rimas paralelas se mantenham nos versos, agrupando-os dois a dois, as rimas internas presentes não mais objetivam a conexão sonora entre versos, mas se concentram ou na singularidade de cada verso, ou no par de versos determinados pelas suas rimas finais:

Tu que tantos difamam, e poucos, como eu, ajoelhados amam. 
Neste "par de versos" determinado pelas rimas paralelas ("amam"), verifica-se no primeiro a aliteração da consoante "t" (tu/ tantos) e a assonância da vogal nasalizada "ã" (tantos/ difamam), proporcionando a sua coesão sonora interna. No segundo verso, a assonância da vogal “o” (poucos/ como/ ajoelhados) garante a rima interna do verso. Percebe-se que, embora seja identificada a assonância da vogal nasalizada "ã”, promovendo a ligação sonora entre os dois versos, todos os outros elementos sonoros descritos reforçam certa independência sonora entre os versos. Ou seja, há uma independência que vem privilegiar o prolongamento sonoro de cada verso, o que, desse modo, resulta num ritmo mais pausado em comparação com a outra fala de D. João, anteriormente analisada.

É preciso ainda ressaltar a presença de ditongos em palavras como "poucos", "Deixa", "Amendoeira", "noite", "mãos", "feita" e, também, aqueles que se formam na ligação de sílabas de diferentes palavras ("comoeu", no segundo verso) e a estratégica posição desses ditongos no interior dos versos, proporcionando a sensação de "alongamento" do som, o que, por sua vez, reforça o tom de resignação, de quase "oração".

Diferentemente da dicotomia na linguagem que se constatou em O fim e em D. João e a máscara; em Pedro, o cru e Dinis e Isabel verifica-se o diálogo em prosa, cuja complexidade se depreende do conflito que se erige fundamentalmente através das palavras. E, inevitavelmente, do qual se expressa a poesia ${ }^{2}$. Assim, a tragédia da saudade, tal como o próprio Antônio Patrício define Pedro, o cru, constrói-se dramaticamente através do verbo:

PÊRO COELHO (narrando a Pedro o momento do assassinato de Inês de Castro)

Foi quando nos olhamos sem falar, e como a pedra cai num poço em noite, a decisão suprema entrou em nós. (...). Era no Outono como agora. Vós lembrai-vos. Sabíamos que iríeis a montear,

2 “A poesia é a expressão natural dos mais violentos modos de emoção pessoal” (MURRY apud MOISÉS, 1997, p. 77). 
e partimos, noite cerrada, para perto. El-Rei vosso pai, meu senhor, fazia dó. (...) por duas ou três vezes quis voltar. (...). Era o dever, o seu dever de rei, que o levava arrastos pela noite...

(...)

Por fim, chegamos. (...). A manhã tinha de vir: e veio!... Daí a pouco, os vossos cães latiram. Soou então uma trompa de monteiro, mas baixo, como quem chamasse a medo. Houve um rumor de porta sob o alpendre... Éreis vós, meu senhor, que íeis montear... (...). Vi então claramente o vosso vulto. (...). Depois Ela... Foi para vós: beijou-vos: não sei o que vos disse...e ouvi-vos rir... Oh! O vosso rir, o vosso rir na inocência da manhã! (...). Descestes. Ela seguiavos com os olhos, debruçada. (...). Ela tinha a mão por sobre os olhos, acenou-vos um adeus lento, (...). Chamei por vosso pai. Disse-lhe baixo: - É a hora, meu senhor. Ele hesitava, branco, cor-de-cera, encostado a um tronco de oliveira, que era mesmo da cor de suas cãs... (...). Demos a volta ao muro do pomar, e eu empurrei a porta — a porta que vós meu senhor, tínheis deixado entreaberta (...). Ela estava ainda sob o alpendre, e olhava do lado do Mondego. Voltou-se então: decerto ouvira os passos... e toda a face lhe embranqueceu de tal maneira, que para que eu não quedasse de piedade, foi meu senhor, lembrar-me de que amava a minha terra (...).

Vi que queria gritar, mas não pode. Ainda olhou num instinto de defesa, para o lado por onde vós sumistes... Quando subi a escada, vi-a abalar com gestos de agonia, para a alcova de vossos filhos. (...). Parecia que um vento de terror a enovelava, assim, movendo os braços como asas, com três vidas pequeninas a cercá-la, (...). E cravara em vosso pai os olhos! (...). Ele tapara os olhos com a mão para não ver os dela, nem os netos; e com uma voz tão branca como o rosto, ela disse ao Infante D. Dinis: - Olha o avô!... (...). Eu desnudei então a minha espada. Avancei para ela. Nem fugiu. Estava sem alma já. (...) Lembro-me que a vi cair ensangüentada, e que ouvi, gelado de estupor, vossa trompa em caça muito ao longe, num halali que em soou em dobre...

PEDRO, como um possesso, em gritos de delírio

O uchão!... Ide chamar-me o uchão!... Vinagre e azeite para este coelho! ( $\mathrm{O}$ carrasco, vestido de escarlate, surge à porta. Pedro aponta-lho) (PATRÍCIO, 1982, p. 90-3) 
Através desse trecho do diálogo entre Pêro Coelho e Pedro, por exemplo, percebe-se que a poesia não necessita do verso para se expressar. E, embora ainda constatemos a presença menos frequente de versos inseridos no diálogo da peça, eles já não revelam o mesmo labor formal que se verificou nas peças anteriormente analisadas. Há, pois, apenas dois pequenos momentos nos quais ocorre essa inserção de versos. No primeiro, Afonso trova a pedido de Pedro:

Sou teu, tu és minha.

Quem morre não parte;

Nem Deus nem a Morte

Puderam levar-te.

No segundo momento, a Primeira Freira cantarola, em versos, referindo-se à forma como outra Irmã costumava fazê-lo quando viva:

\author{
Sabedoria, \\ sabedoria, \\ sabedoria \\ de rouxinol: \\ cantar à noite, \\ dormir de dia, \\ fugir ao sol. (Ibid., p. 101)
}

Verifica-se, todavia, que, nesses dois momentos, esses versos não apresentam desdobramento significativo para $\mathrm{O}$ desenvolvimento do drama. Na verdade, acham-se praticamente "soltos", o que poderia revelar, por sua vez, uma inexpressão da forma exterior em detrimento de uma interior que se constrói tragicamente ao longo de toda a peça, tal como vimos no trecho do diálogo entre Pero Coelho e Pedro. Essa supremacia da forma interior sobre a exterior parece transparecer certo abandono do autor (Patrício) por uma exclusiva expressão poética através de versos, revelando nesta peça a preferência pela "fôrma" da prosa no lugar do verso para expressar poesia, o que, sem dúvida, resultou em maior complexidade da linguagem: o diálogo dramático da peça constitui prosa ou poesia? Prosa poética? Drama lírico? 
Certamente que uma tentativa de classificação do diálogo em Pedro, o cru, tendo em vista critérios estritamente formais, revelar-se-ia ineficaz. Isso porque, apesar da ausência do verso, verifica-se, principalmente nas falas de Pedro, a expressão de emoções das mais profundas, revelando grande tensão e angústia - momentos de puro devaneio:

PEDRO (em Alcobaça, falando com o cadáver, madrugada que antecede à coroação e ao beija-mão de Inês de Castro)

É a nOssa hOra, InÊES... EStamOS sozinhOS. EstáS bem aSSIM!? Tu ouve-me dormINdo. Eu fico aqui à tUa cabeceira. Não bUlas, meu amor, dorme assim queda - como a Tua es'TáTua ali, sobre o $\mathbf{T}$ eu Túmulo... Esta é a casa De Deus. Deus está connosco. Ouve S OS Sin OS repicar!? Toca AnoivAdo. AS nOSSAS bodAS AgOrA - São etern $\boldsymbol{A S}$. Sinto nA minha Alma $\boldsymbol{A}$ tua Alma - como a Água de uma fonte noutra fonte, como a luz na luz, e Deus em Deus... Sin $\boldsymbol{T}_{0}-\boldsymbol{T e} \boldsymbol{T}$ an $\boldsymbol{T}_{0}$, quE $\boldsymbol{T} \boldsymbol{E}$ pErco em mim. Aqui me tENS, In $\hat{\boldsymbol{E}} \boldsymbol{S}$ : sou o teu Pedro. $\boldsymbol{O}$ que ele tem, o que ele $\boldsymbol{T E m}$ para $\boldsymbol{T E}$ con $\boldsymbol{T}$ ar!... Eu bEm sEi quE TU sabEs... sabEs $\boldsymbol{T} \boldsymbol{T} d o$. Os teus $\boldsymbol{O U V}$ idos, na Morte, OUVEm mElhor. OUViram o dEs $\boldsymbol{E}_{s}$ e Er $\boldsymbol{O}$ d $\boldsymbol{O}$ tEu PEdr $\boldsymbol{O}$ - uma noitE dE pEdra sobrE Esta AlmA - OUViram AS suAS lágrimAS cAlAdAS: OUViram toda, toda a sua dor. (...) Ob! Os meus dias... os meus longos dias - longos dIas de bIena trIste, a Sonhar Sangue... O teu Pedro quer mostrar-tos para que os beije: - e serão puros na Saudade, como tu. MII vezes, MInha Inês, MII vezes sofrI na mInha caRne a tua moRte. Via-o sempre - o espaço era para ele - o teu corpo de amor, tão grande e belo. Deixei de ver o sol: via-o a ele. Vivia com teu c $\boldsymbol{O}$ rp $\boldsymbol{O}$ na memória $-c \boldsymbol{O} m \boldsymbol{O}$ um $l \boldsymbol{O} b \boldsymbol{O}$ n $\boldsymbol{O}$ f $\boldsymbol{O} \boldsymbol{j} \boldsymbol{O}$ cOm a presa. (...).

VIvI um ano ass Im, do teu martÍrIo. O teu sangue, aMor, era o Meu vinho. A tua Morte, Inês, foi o Meu pão. Fugia ao sol: a luz envenenava-me. Queria estar só, bem só, Murado em Mim: - cavava no silêncio um fojo escuro para me podeR cevaR na minha doR. O Meu crânio era uMa câMara de Tor'Tura:- viviam lÁ um carrASco e oS aSSaSSinoS.(...). (Ibid., p. 166-7) ${ }^{3}$

Percebe-se através das marcações, apesar da ausência do verso, um exaustivo trabalho sonoro resultante das aliterações, assonâncias e repetições que ocorrem ao longo de todo o trecho. 3 As marcações em maiúsculas indicam os sons expressivos dos recursos
sonoros utilizados: aliteração, assonância, repetições, rimas. 
Ou seja, mais uma vez, a forma conjugada ao conteúdo expresso vem expressar poesia.

É importante ressaltar, ainda, que ao longo do extenso devaneio que constitui a fala de Pedro, quando se dirige à Inês morta, verifica-se um dualismo quanto à pessoa do discurso. $\mathrm{Na}$ realidade, expressa-se na forma a própria cisão da psique de Pedro que, mergulhado no seu sofrimento, desdobra-se em dois: o Pedro sem Inês - "a hiena que o cio ensandeceu, o rei coveiro de chicote e coroa" (Ibid., p. 158) - ; e o Pedro de Inês - "Aqui me tens Inês: sou o teu Pedro" (Ibid., p. 165). No trecho abaixo, podemos verificar, assim, o dualismo que se expressa no seu discurso, o qual oscila ora concordando em primeira pessoa, ora em terceira pessoa:

Aqui me tens Inês: sou o teu Pedro. O que ele tem, o que ele tem para te contar! (...). Os teus ouvidos, na Morte, ouvem melhor. Ouviram o desespero do teu Pedro. (...). Ouviram toda a sua dor. (...). Os meus dias... os meus longos dias - dias de hiena triste, a sonhar sangue... O teu Pedro quer mostrar-tos para que os beijes (...). Mil vezes, mil vezes sofri na minha carne a tua morte. (...) E o carrasco era eu, era o teu Pedro. (...) E às vezes nas palmas destas mãos, quase sentia a polpa dos seus seios!... Era um lobo o teu Pedro. (Ibid., p. 165-7)

Em seguida, o seu desvario encontra o desfecho na fusão de Pedro e Inês que ocorre na Saudade.

PEDRO, dirigindo-se ao cadáver de Inês:

E eu vi a Saudade ao pé de mim. Nunca mais me deixou: vivo com ela. Fez-se em mim carne e sangue. Fez-se Inês. (...). Por isso eu sei a morte como tu. Sou o homem que viveu a vida e a morte: sou o homem-Saudade, o rei-Saudade. (Ibid., p. 167)

Assim, através desse encontro simbólico de Inês e Pedro, ocorre a reconstituição de sua psique, desfazendo-se a cisão "Pedro sem Inês" / "Pedro de Inês": 
(...). Onde estou eu?... Não sei. Estou só contigo. Respiro o teu olhar: é luz de luz.. É o ar da minha alma - o teu olhar. E Alcobaça!?... A minha coroa de oiro!?... Alcobaça onde está!?... as altas naves!? E os sinos?... a corte!? Os sinos a baliar no ar as minhas bodas!?... Ainda os oiço... ainda... mas tão longe... É o princípio e o fim de tudo o nosso amor. Os teus seios uniram-se: ei-lo - o mundo!... Oiço no teu silêncio cotovias... O som e a luz casaram-se, fundiram-se: são o ar que eu respiro... o nosso ar... Oh! Asas... asas... dêem-me asas//1... É um abismo de estrelas - este amor... faz-me medo. É um turbilhão de estrelas... Inês!... Inês!... Eu tenho medo... Sinto o vento de luz da eternidade... (Ibid.: p. 169)

Se em Pedro, o cru, em D. João e a máscara e em O fim encontramos o dualismo poesia/prosa, que se expressava explicitamente na linguagem através da ausência/presença do verso e de uma prosa predominantemente poética, em Dinis $e$ Isabel já não se verifica a presença do verso. Todo o diálogo se elabora em prosa, entretanto, expressa poesia como nas demais peças.

Consistindo, pois, o teatro em uma fôrma literária pertencente à prosa e diante do caráter singularmente híbrido que apresenta a linguagem dos textos teatrais de Patrício, certamente, todos os seus dramas poderiam levar o rótulo de prosa poética ${ }^{4}$. Entretanto, Dinis e Isabel, por tratar-se, segundo definição do próprio Patrício, de um "conto de vitral em cinco atos", um "Conto de Primavera", por que a necessidade da roupagem teatral? É a questão que de imediato poderíamos nos colocar. O próprio Patrício responde ao que, de início, poderia consistir num hibridismo inconciliável de gêneros. Segundo ele, trata-se de "uma pequena tragédia, toda íntima, sem as indicações de costumes ou cenários mais que as estritamente indispensáveis

\footnotetext{
4 “Tão profundamente se operou a simbiose dos dois gêneros (poesia e prosa) ao longo da hegemonia simbolista que nenhuma obra em prosa escapou do seu fascínio(...)" (MOISÉS, 1997, p. 22).
} 
para situar um drama de consciências. (...) Chamei-lhe (...) Conto de Primavera, porque me pareceu resumir assim a intenção toda lírica do conto: - dar, dramatizada, uma visão de Livro de Horas" (PATRÍCIO, 1982, p. 180. Grifo meu).

Daí a sua linguagem poder ser classificada, sem dúvida, como prosa poética. Trata-se de um diálogo dramático em prosa, mas que, pela musicalidade e pelo conteúdo expresso, veicula poesia, como se pode comprovar no trecho abaixo:

PRIMEIRO LEPROSO, tocando as folhas da figueira

Olha a figueira. Como está tão tenra!... E não tem nojo - vê - posso beijá-la. Dá-se a um gafo como a um são: é boa, boa. Há poucos dias toda encarquilhada; agora apetece mordê-la de tão fresca... (Ibid., p. 183)

Assim, embora não identifiquemos explicitamente o dualismo verso/prosa no diálogo dramático de Dinis e Isabel, continua pertinente a sua classificação em prosa poética, visto permanecer o dualismo poesia/prosa, tal como expressa o trecho acima destacado. Ou seja, se no drama D. João e a máscara verificamos que a mudança na linguagem (verso/prosa) marcava, entre outras coisas, uma distinção de personagem, uma vez que apenas quando D. João se dirigia à Morte é que o diálogo se estruturava em versos; em Dinis e Isabel verifica-se um dualismo não apenas formal, mas também semântico. Depreendendo-se, deste modo, a tensão que se constrói entre um homem, um rei plantador de pinheiros, e uma mulher que se elevou à dimensão de uma Santa. Trata-se, pois, da história de um homem que amou uma Santa e que, portanto, perdeu-a para Deus:

DINIS, com amargura baixo

Mesmo com os teus seios nestas mãos, não há asa mais longe no céu alto.

ISABEL

Não sou eu, Dinis amigo, vossa?...

DINIS

Sois mais da erva que pisais a medo. Sois de Deus, de todos. Não sois minha. 
ISABEL, em eco, a voz velada

Não sou vossa, meu Dinis?... não sou?...

DINIS

Nem que quisésseis, Isabel. Era impossível. Não sois, não sois e nunca fostes minha. Vós não vos pertenceis, sois toda d'Ele.

(...)

$\mathrm{O}$ teu desejo tem raiz no céu. Não tem raiz na terra como o meu. É irmão das rosas brancas ${ }^{5}$ que me matam... É em tudo assim, amiga minha, em tudo. P'ra ti as árvores são braços que te apontam as estrelas. P'ra mim são criaturas verdes. O meu sangue é irmão da sua seiva. P'ra mim não há cheiro melhor do que o da terra. Gosto de a esfarelar entre os meus dedos. Tu, numa fossa de leprosos, aspiras um aroma de açucenas que nos cristais do ar abrem sem caule... Como hás de beijar a minha carne? Só podendo sentir em cada poro a essência de dor que te fascina. Não, não; não é a mim que beijas.... (Ibid., p. 237-8)

Percebe-se, no trecho, novamente, a dicotomia expressa na linguagem, através da oposição Dinis versus Isabel que, por sua vez, revela a oposição matéria versus espírito, imanência versus transcendência, respectivamente. Daí as árvores serem para Dinis apenas "criaturas verdes" com o caule cravado na terra e para Isabel, "braços que apontam as estrelas", simbolizando a sua ligação com o Divino e, portanto, expressando a idéia de transcendência.

Vale ressaltar, entretanto, que nesse trecho a poesia revelada decorre não apenas de um expediente semântico, mas também da sua forma. Embora os recursos sonoros se encontrem trabalhados de modo mais sutil, não se pode desprezar a presença da musicalidade no texto.

Uma certa homogeneidade da linguagem a que presenciamos é, pois, apenas aparente, uma vez que a prosa é tão somente epidérmica. Isso porque, se decompusermos as falas que, aparentemente, estruturam-se em prosa, verificaremos que na

\footnotetext{
${ }^{5}$ Dinis se refere às rosas brancas como expressão de um "mal”, porque há um momento no qual Isabel saía com pães escondidos para entregá-los aos mendigos e Dinis a questiona na tentativa de impedi-la, então, quando ordena á Isabel que mostre o que trazia escondido, ela abre os braços e caem rosas brancas, não pães: eis o milagre das rosas.
} 
verdade elas se constituem de versos justapostos, compreendendo inclusive estruturas rítmicas, das quais, aliás, resulta a musicalidade dos diálogos, tal como se comprova nesta mesma fala de Dinis:

O teu desejo tem raiz no céu. Não tem raiz na terra como o meu. É irmão das rosas brancas que me matam. É em tudo assim, amiga minha, em tudo. P'ra ti as árvores são braços que te apontam as estrelas. P'ra mim são criaturas verdes. O meu sangue é irmão da sua seiva. P'ra mim não há cheiro melhor do que o da terra. Gosto de a esfarelar entre os meus dedos. Tu, numa fossa de leprosos, aspiras um aroma de açucenas que nos cristais do ar abrem sem caule... Como hás de beijar a minha carne? Só podendo sentir em cada poro a essência de dor que te fascina. Não, não; não é a mim que beijas.

Decompondo-a, então, temos:

O/ TEU/ de/se/jo/ TEM/ ra/iz/ no/ CÉu/ decassílabo heróico

$\begin{array}{llllllllll}1 & 2 & 3 & 4 & 5 & \mathbf{6} & 7 & 8 & 9 & \mathbf{1 0}\end{array}$

Não/ TEM/ ra/IZ / na/ TER/ra/ co/mo o/ MEu/ (decassílabo heróico)

$\begin{array}{llllllllll}1 & 2 & 3 & 4 & 5 & \mathbf{6} & 7 & 8 & 9 & 10\end{array}$

É ir/MÃO/ das/ RO/sas/ BRAN/cas/ que/ me/ MA/tam (decassílabo heróico)

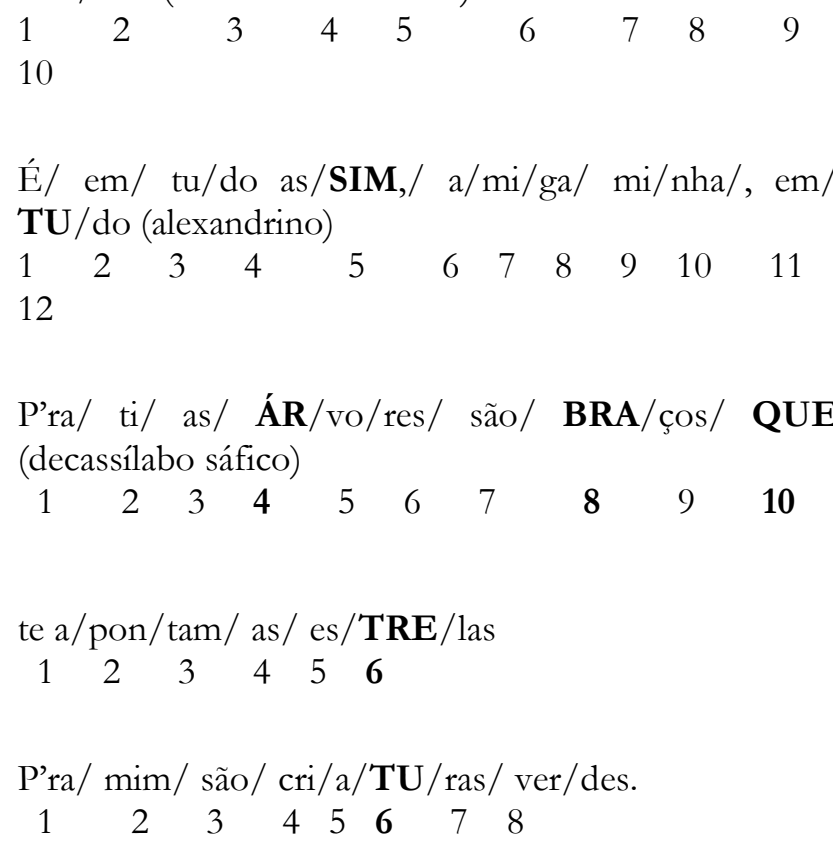




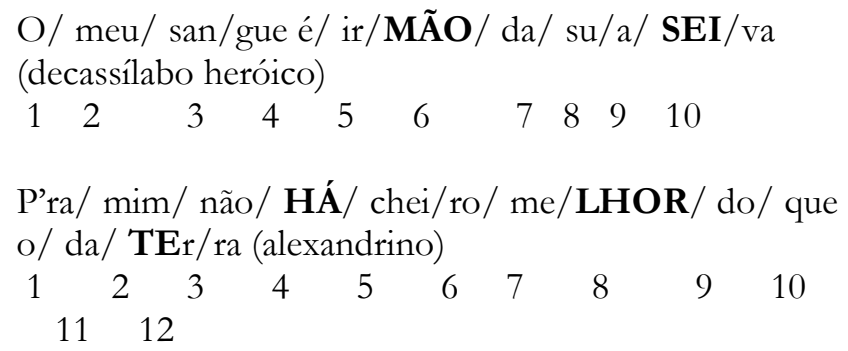

Gos/to/ de a es/fa/re/LAR/ en/tre os/meus/ DE/dos. (decassílabo heróico)

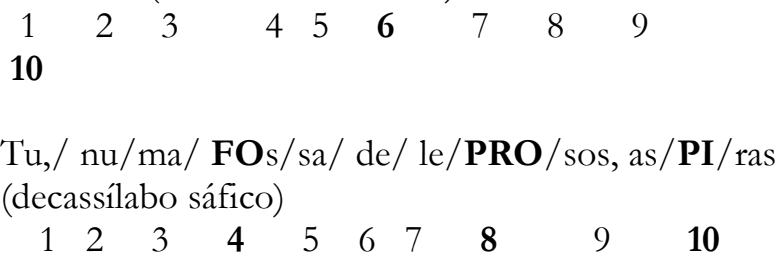

Verifica-se que, para uma análise satisfatória da linguagem dos dramas de Antônio Patrício, é necessário levar em conta uma distinção entre verso e poesia, não tomando $\mathrm{o}$ verso simplesmente como sinônimo de poesia. Este equívoco tem sido recorrente porque, há milênios, tem-se buscado a distinção entre prosa e poesia como "algo exterior, isto é, formal", tal como propunha o linguista Karl Vossler (apud MOISÉS, 1997, p. 76). Para ele, a poesia coincidiria com uma "aparência simétrica" e a prosa, com uma "aparência assimétrica".

Assim, partindo desse critério, começou-se a "identificar a poesia com o verso", o que se afigurou, todavia, "uma visão superficial do problema”. Entretanto, percebendo a precariedade do critério, o próprio linguista se antecipou completando que "atrás da relação externa sem dúvida há de esconder-se outra interna”. Sob essa nova perspectiva, seria possível, então, estabelecer uma distinção através da "forma interior" e "a forma passaria a ser encarada de modo adequado, como estrutura, não como mera aparência gráfica", ou seja, "a discriminação epidérmica cede lugar a uma distinção profunda, embora de cunho formalista" (Ibid., 76).

Focalizando-se, portanto, uma "forma interior", a esta corresponderia uma certa "temperatura" ou "tônus", decorrente 
justamente da presença de uma "emoção humana" nesse tipo de texto e que o distinguiria, assim, enquanto poesia. Ora, sob essa perspectiva, não há do que se duvidar quanto à marcante presença poética que se verifica em todas as peças de Antônio Patrício, cuja dramaticidade se exprime justamente em conflitos interiores às personagens.

Vale ressaltar, ainda, que, se "o objeto da poesia é o reino infinito do espírito” (Bonnet apud Moisés, 1997, p. 84), reino este que é a expressão do "eu”, temos então que "a poesia é a expressão do 'eu' pela palavra”. De acordo com essa distinção entre prosa e poesia, não se pode contestar a sua evidência nos versos que compõem a obra dramática de Patrício, tal como pudemos entrever nos trechos anteriormente destacados e analisados.

Verifica-se, assim, que todo o diálogo que se elabora nas peças de Patrício — seja em prosa, seja em verso — apresenta um forte tom poético, o que já descaracterizaria, deste modo, qualquer tentativa de justificar a presença poética levando-se em conta apenas o uso do verso. Ou seja, trata-se de textos teatrais, os quais se caracterizam como narrativa dialogada ${ }^{6}$ e se apresentam ora em forma de poema, ora em forma de prosa, mas indubitavelmente identifica-se forte "presença" poética tanto no seu aspecto formal quanto semântico.

Em decorrência, portanto, desse hibridismo (teatro/prosa e verso/poesia), encontramos na crítica diferentes abordagens da obra dramática de Patrício, ora classificando-as como "poesia dramática", ora como "drama poético", comprovando a complexidade de sua estrutura tanto exterior como interior. Ou seja, a complexidade que se constata na linguagem, decorrente

\footnotetext{
${ }^{6}$ Massaud Moisés (Op. cit., pp. 124-130) caracteriza todo texto teatral como "narrativa dialogada".

7 Consta do acervo da Biblioteca Nacional de Lisboa teses acadêmicas buscando uma classificação satisfatória acerca do gênero no qual se enquadraria a produção dramática de Patrício, como o trabalho de Alexandra Maria Fernandes Silva, intitulado Poesia e Teatralidade, Universidade de Coimbra, 1996; além do conhecido texto de Manuel Tanger Correia, "Antônio Patrício, poeta trágico”, Lisboa, 1960.
} 
desse hibridismo de gêneros, faz com que todos os outros elementos (ação, espaço, tempo e personagens) se encontrem a ela submetidos, o que, por sua vez, faz com que na análise de cada um desses elementos sejam os demais naturalmente evocados.

Vale dizer, portanto, que abordar a linguagem no texto teatral, em especial, traduz-se numa complexa equação, uma vez que é nela que se espelham as suas intrínsecas dicotomias. A primeira dicotomia inerente ao texto teatral e que se revela na linguagem diz respeito à própria natureza do texto teatral (teatro versus literatura), visto que, embora em tese ele se destine à representação, a linguagem nele empregada segue padrões literários. Ou seja, "o texto dramático se alimenta da linguagem literária para se erigir como espetáculo" (MOISÉS, Op. cit., p. 1245): enquanto as rubricas - indicações de cenário ou de fala pertencem ao espetáculo, visto interessarem apenas ao encenador; ao leitor e ao crítico literário restam exatamente aquilo que, em teoria, deveria lhes interessar, ou seja, a sequência de diálogos. Assim, como "arte do diálogo, o teatro distingue-se como uma narrativa dialogada", uma vez que é por meio do diálogo que um conflito se constrói e "se manifesta numa trama ou enredo, com início, meio e fim" (Ibid., p. 125). Chegamos, desse modo, à segunda dicotomia do texto teatral revelada pela linguagem: "como pode ser narrativa, portanto, exibir os componentes adequados, e ser tão-somente dialogada?”' (Ibid., p. 126)

Verifica-se, portanto, que da primeira dicotomia surge a segunda. Entretanto, é preciso pontuar corretamente as diferentes naturezas que o diálogo do texto dramático abriga: como diálogo literário deve bastar-se em si mesmo, "na medida em que remete para a personagem que o enuncia, por sua vez existente como ser fictício"; entretanto, o diálogo dramático só se realiza quando ganha a voz e a interpretação do ator, uma vez que o dramaturgo visa à encenação do texto, supondo não apenas a leitura dos 
diálogos, mas a sua "verbalização em voz alta e dirigida a um público". (Ibid., p. 127)

Colocadas essas duas dicotomias inerentes a todo texto teatral, resta-nos ainda apontar uma terceira que se configura exclusivamente no texto teatral simbolista e que, como ocorre com as anteriores arroladas, expressa-se pela linguagem. Isso porque, como se sabe, o teatro simbolista vem explicitamente ditar a supremacia do texto, afirmando-se, sobretudo, através das palavras, como ressalta Mallarmé: "a peça simbolista deve ser lida sob a luz de uma lâmpada solitária" (apud BARATA, 1991, p. 307). Deve assim ser lida, porque os elementos de que lançam mãos os simbolistas não pretendem uma representação concreta, embora não signifique, todavia, que não visem a uma forma de representação. Ou ainda, como ressalta L. F. Rebello (1968), "há um teatro do verbo e um teatro do gesto".

Assim, a preferência simbolista por um "teatro estático", no qual se tem mais "a ilustração de uma idéia" que uma "ação efetiva", não resulta na impossibilidade de consenso entre o Simbolismo e o teatro. Há, pois, no teatro simbolista um conflito que se expressa na palavra, resultando numa "espetacularidade verbal" (Ibid., p. 80).

E como espetáculo verbal, a que visaria o diálogo no teatro simbolista? Ora, como texto eminentemente literário que é, visa à leitura (lembrando as palavras de Mallarmé) e tão-somente à leitura! Se isto é verdade, então, qual seria a razão para as indicações cênicas? A sua razão reside, talvez, na existência de uma proposta de encenação, mas não uma encenação de fato. Pretende, isto sim, como simbolista que é, uma encenação mental, singular, única em cada leitor, o qual ainda se converte, ao mesmo tempo, em encenador e espectador de sua projeção mental. Sob essa perspectiva, o teatro simbolista propõe, então, uma inversão naquela máxima de todo texto teatral - "ser o máximo fora (no palco) e o mínimo quando em si (o texto)" (MOISÉS, 1997, p. 128) - impondo, assim, o contrário: o texto teatral simbolista 
busca o máximo quando em si e quase a sua nulidade fora (no palco).

Dessa forma, nessa proposta de encenação internalizada, o leitor/espectador deve lançar mão dos seus recursos imagéticos, tal como o faz o leitor da poesia simbolista, buscando nas camadas mais profundas da consciência (e do inconsciente) os elementos necessários à leitura/encenação do drama simbolista. Dessa busca, emergem, portanto, imagens e elementos arquetípicos que, por sua vez, poderiam explicar, por exemplo, a preferência de Patrício por personagens míticas. Na verdade, o dramaturgo simbolista parece "brincar de demiurgo", mas não na esfera do mundo material. Sua pretensão está além, remontando todo o mundo interior do Homem, sua consciência e, principalmente, seu inconsciente.

Assim sendo, poder-se-ia questionar que, se o autor simbolista, entregando-se a um desregramento, vai buscar nas camadas mais recônditas do ser a consciência primitiva, ocultada pela civilização, a consciência anterior ao $\log 0 s^{8}$, como então conceber a presença de uma narrativa dialogada expressa pela linguagem? Sendo a narrativa, pois, elemento intrinsecamente organizado segundo uma ordem da consciência?

$\mathrm{Na}$ realidade, a narrativa que se verifica nas peças de Patrício serve apenas de instrumento para que o mito seja recuperado. Trata-se da "narrativa mítica": verifica-se a existência de uma estrutura mítica introjetada na linguagem. Estrutura esta que seria responsável pelo estabelecimento de um "movimento" na linguagem, do que se depreende, por sua vez, a ação expressa pela palavra, pelo mito, pelos arquétipos.

Temos, desse modo, que da análise da linguagem, inevitavelmente, emergem a ação, as personagens, o tempo e o espaço, na medida em que todos esses elementos se constroem

\footnotetext{
8 Álvaro Cardoso Gomes (1985, p. 18) explica: "O desregramento a que se entrega o poeta é uma tentativa de recuperar a consciência primitiva, que a civilização ocultou, no instante em que instituiu a fatal e definitiva separação entre o homem e a Natureza. Ora, é esta consciência anterior ao logos que possibilitou ao homem decifrar os símbolos do Universo".
} 
através da linguagem. E, ainda, devido à proposta da estética simbolista, que tem como núcleo a inovação da linguagem e da expressão, a linguagem ganha maior complexidade, visto amarrar em sua própria constituição todos esses elementos. Decorrendo justamente disso a grande dificuldade em se tentar analisar cada elemento em separado e, por fim, resultando numa análise que, necessariamente, evoca em cada item a presença de todos os outros elementos.

\section{BIBLIOGRAFIA CITADA:}

CAMELO, José Antônio; PECANTE, Maria Helena. Dom João e a máscara: textos e notas de leitura. Porto, Porto Editora, 1992.

CORREIA, Manuel Tânger. António Patricio (poeta trágico). Separata da Revista Occidente, vols. LVII e LVIII, Lisboa, 1959/60.

BARATA, José Oliveira. História do teatro português. Lisboa, Universidade Aberta, 1991.

GOMES, Álvaro Cardoso. A estética simbolista. São Paulo, Cultrix, 1985. MOISÉS, Massaud. A criação literária: prosa II. 19. ed. São Paulo, 1997.

PATRÍCIO, Antônio. Teatro completo. Edição 147, Lisboa, Assírio e Alvim, 1982.

PICCHIO, Luciana Stegagno. História do teatro português. Lisboa, Portugália, 1969.

REBELLO, Luiz Francisco. História do teatro português. Coleção Saber. Lisboa, Europa-América, 1968.

RÉGIO, José. "Sobre o Teatro de Antônio patrício". In: Estrada larga, vol. II. Porto, s/d.

RODRIGUES, Urbano Tavares. O mito de D. Juan e do donjuanismo em Portugal. Lisboa, 1960.

MURRY, J. Middletton. El estilo literário. Tr. Mexiana. México-Buenos Aires, Fondo de Cultura Econômica, 1951.

Abstract: By an analysis of Antonio Patricio's dramas and their language, this article intends to discuss the existence or not of symbolist drama in his playwriting. The uniqueness of his dramas is based in the tension between prose and poesy; this feature, instead of invalidating the existence of a symbolist drama, consists in one of the fundamental elements in which symbolism finds a sustenance possibility, by it's verbal spetacularity.

Keywords: portuguese drama; symbolism; decadent art; Antonio Patrício. 